\title{
Development of Physics Communication Skill Instruments Based on Local Wisdom for Senior High School Students
}

\author{
Rizki Ageng Mardikawati ${ }^{*}$, Mundilarto ${ }^{2}$ \\ 1,2 Physics Department, Graduate School of Yogyakarta State University, Yogyakarta \\ e-mail: rizkiagengmardikawati@gmail.com, mundilarto@uny.ac.id
}

\begin{abstract}
This research aims to develop physics communication skill instruments based on local wisdom for Senior High School Students. The development step was adopted special research for non-test developed by Mardapi (2012). There are ten steps for developing an instrument, such as 1) arrange the specification of the instrument, 2) write the instrument, 3) determine the scale, 4) determine scoring system, 5) recheck the instrument, 6) do the pre-test 7) analyze the instrument, 8) make the final instrument, 9) do the measurement, and 10) analyze the result of the measurement. The communication skills are measured by verbal aspects use the observation sheet through the presentation. Meanwhile, the nonverbal aspect uses the portfolio. This instrument is validated by three experts in evaluation, physics, education, and three teachers of a senior high student. Communication skills consist of five indicators. This study is participated by 33 students of SMA IT Ihsanul Fikri. The content validity was analyzed with the $V$ Aiken formula show that the overall coefficient of each item was valid with the validity coefficient $\geq 0.78$. The instrument also reliable with coefficient $G$ Relative $\geq 0.7$.
\end{abstract}

Keywords: Local Wisdom; Communication Skill; Verbal

\section{Introduction}

Indonesia is a rich country in culture. Besides being famous for its abundance of history, views, and languages, the country also has priceless local wisdom. Local Wisdom is a harmonious relationship between humans, nature, and the environment in a particular area. This relationship is influenced by the local culture (Pornpimon, Wallapha, \& Prayuth, 2014). There are various types of local wisdom such as culture, traditional games, food, place, until local art. Local wisdom is a valuable asset that must be preserved. The influence of globalization that is characterized by technological development makes people forget about this local wisdom (Mungmachon, 2002). It is natural that students at school no longer recognize the potential of local wisdom in their region due to the effects of globalization (Dewi, Poedjiastoeti, \& Prahani, 2017).

Today's educational world is faced with a trend known as $21^{\text {st }}$-century learning (Dass, 2014). Two major challenges are facing the $21^{\text {st- }}$ century society, namely the astonishing cultural and evolutionary paradigm of information and communication technology (Mustea, Mure, \& Herman, 2014). This model demands achievement in all aspects of the skill. These aspects include 1) learning and innovation skills; 2) information, media, and technology skills; and 3) life and career skills. Learning skills are divided into three main parts; information and communication skills, thinking and problem-solving skills, as well as interpersonal and independence (Ongadwanich, Kanjanawasee, \& Tuipae, 2015)

This communication skill becomes an important factor in 21st-century learning (Musa, Mufti, Latiff, \& Amin, 2012). Communication is one's way of expressing ideas, including learning. Through communication, students will have a new perception of learning (Mastura, Soh, Mohamad, \& Osman, 2010). Practicing thinking to communicate something will make students have a better understanding of physics (Lou, Wu, Shih, \& Tseng, 2010). Student mastery in communication skills is essential to improve the quality of learning. Communication skills are needed in all domains, especially science learning (Series, 2018). One branch of science that requires communication skills in its application in physics.

\footnotetext{
* Corresponding author.

Received 9 February 2019; Accepted 3 June 2020; Available online 20 June 2020

(C) 2020 JPI. All Rights Reserved
} 
Physics is a science that challenges and learns it is an adventure (Young \& Freedman, 2001). Learning physics includes $21^{\text {st }}$-century skills on student's attitudes (Mastura, Soh, Mohamad, \& Osman, 2010). Lack of student understanding of the concept of physics in the classroom, making students not confident enough to just express opinions (Fahmi, 2017). Communication that occurs is still limited to teacher-centered and less involving students. Good learning demands positive interaction between teachers and students (Curwood, Tomitsch, Thomson, \& Hendry, 2015). This positive interaction can produce a fun learning process that makes students grow (Trifu, Trifu, \& Trifu, 2016).

This lack of students' understanding and self-confidence begins with physics learning in the classroom (Klisc, McGill, \& Hobbs, 2009). Students tend to be passive because they only listen to the material. Some students become bored and do not focus on the material being taught (Gok \& Sylay, 2010). When studying physics, students should be able to relate it to daily life. This ability is related to one skill, which is communication skills (Demir, 2014). The lack of ability of students in communicating physics in the class one of them caused by foreign terms of physics they encountered (Kohl \& Finkelstein, 2005). It needs innovation to make students motivated in learning physics so that the learning result is also maximal ( $\mathrm{Ho}$, 2014).

Concerning communication skills and the introduction of local wisdom in the students, a bridge was found, namely the development of physics communication skills based on local wisdom. That way, students learn two things at the same time. Previous research has been developed by Fahmi (2017) resulted that this learning is effective enough to explore students' communication skills. Learning adapted from local wisdom will certainly be a unique novelty for students. On the other hand, students will find new learning models to overcome the saturation of physics learning in the classroom. While on the other hand, students can preserve the local culture as well as to train physics communication skills.

Internalizing local wisdom on learning in schools has many benefits for students (Adilah \& Saputra, 2013). This is motivated by students less familiar with local wisdom potential in their area (Setiawan, Innatesari, \& Sabtiawan, 2017). The insertion of local wisdom into the subject can improve students' perceptions of the introduction and potential of the region (Bakhtiar \& Nugroho, 2016). Currently, there are not many subjects in schools whose material is integrated with local wisdom, including physics subjects.

Appropriate assessment of the model will help maximize the model's achievement when implemented to students (Yusuf, 2015). This kind of assessment can be used as a standard for evaluating the learning that has been done (Weeden \& Broadfoot, 2002). The teacher is still having difficulty in compiling this communication appraisal. Developing an assessment worksheet is more effective in terms of developing basic and integrated science process skills for teachers (Aydo \& Kartal, 2013). The time limitations possessed by the teacher to think and design the assessment are one of the things that causes this. Teachers tend not to use assessment instruments that match the material characteristics and tasks assigned to students (Hodosyova, Utla, Vnkova, \& Lapitkova, 2015). In addition, the instruments used by teachers also do not have reliable and valid evidence.

This research specifically uses local wisdom in the form of a traditional game of gasing and traditional wayangan art. Students are invited to explore themselves through the integrated assessment of local wisdom to sharpen communication skills. The selected material is Rotational Dynamics for Senior high school grade XI. This research aims to produce a valid and reliable verbal and nonverbal communication physics assessment instrument.

\section{Method}

This study was conducted at SMA IT Ihsanul Fikri Mungkid Magelang on March-May 2018. About 33 students in grade XI participated. This study uses specific guidance on the development of assessment instruments. Ten steps must be taken in preparing non-test instruments according to Mardapi (2012), namely 1) arrange the specification of the instrument, 2) write the instrument, 3) determine the scale, 4) determine scoring system, 5) recheck the instrument, 6) do the pre-test 7) analyze the instrument, 8) make the final 
instrument, 9) do the measurement, and 10) analyze the result of the measurement. To conform to the objectives of the study, we can limit them to two stages: instrument design and content validity analysis. The instrument design stage begins by specifying the detailed test specs. The developed instrument is used to measure verbal and nonverbal communication skills. Verbal ability is the ability of students in discussing and presenting their work. While the non-verbal capability measured in the form of students' ability in preparing reports.

The design of the test instrument begins with the determination of the operational definition of communication, then continues to be an indicator to assess students' communication skills. Five indicators are obtained to measure the ability of verbal communication which then uses a Likert scale for assessment. While on the assessment of non-verbal communication skills, used criteria to assess student achievement. This criterion is used at the same time to establish the system of the scoring system. After the portfolio and observation sheets have been completed, the next step is expert judgment and then revised the script based on existing input.

Data analysis of validation result obtained through the validation sheet of assessment instrument by expert lecturer and practitioner is done as follows; 1) The validity of the grains of the developed test appraisal instrument is sought by using the Aiken $\mathrm{V}$ test (Aiken, 1985). The formula to find out the content validity coefficient is as follows: The minimum Aiken's $V$ index is said to be valid to be adjusted to the table of validity coefficients. To test its reliability, the EduG app is used. Genova analysis is used to test the reliability of non-test instruments. The test is said to be reliable if the Genovere coefficient value is more than 0.7

\section{Result and discussion}

The main title of the instrument produced in this research is an observation sheet to measure the ability of verbal communication and portfolio sheet to measure the ability of non-verbal communication. The following table rubric assessment of communication skills measured, consisting of 5 indicators and 16 aspects. The indicator and aspect of verbal communication skills are described in Table 1.

Table 1. Indicator and aspect of verbal communication skill

\begin{tabular}{cll}
\hline Num & \multicolumn{1}{c}{ Indicator } & \multicolumn{1}{c}{ Rated aspect } \\
\hline 1. & $\begin{array}{l}\text { Present the } \\
\text { presentation in a } \\
\text { straight forward } \\
\text { manner }\end{array}$ & $\begin{array}{l}\text { Delivering the main points during the presentation } \\
\text { Delivering in a language that is easy to understand } \\
\text { Delivering results based on group / experimental discussions } \\
\text { Present the presentation politely }\end{array}$ \\
\hline Master the material & $\begin{array}{l}\text { Able to present the information obtained } \\
\text { Able to link information obtained with existing physics concepts } \\
\text { Able to evaluate the information obtained } \\
\text { Able to analyze the information obtained }\end{array}$ \\
\hline presented & Able to answer & $\begin{array}{l}\text { Answering questions as they are asked } \\
\text { Answering by the concept of physics being discussed } \\
\text { Answering coherently } \\
\text { Answer clearly and uncomplicated }\end{array}$ \\
& Bestions & $\begin{array}{l}\text { Provide opportunities for other students to argue } \\
\text { Easy to accept criticism and suggestions } \\
\text { Able to be honest / not stubborn } \\
\text { Not shy to change opinions if wrong }\end{array}$ \\
\hline
\end{tabular}

Assessment using Likert scale with rating scale 1 to 4 with description, 1 = not good; 2 $=$ less good; $3=$ good and $4=$ very good. While rubric assessment of non-verbal communication skills is given in Table 2 as follows. 
Table 2. The aspect of Non-Verbal Communication Skill

\begin{tabular}{cl}
\hline Num & \multicolumn{1}{c}{ Aspect } \\
\hline 1 & $\begin{array}{l}\text { Complete the report component: title and purpose, work steps, table of observations; data } \\
\text { analysis, conclusion. }\end{array}$ \\
2 & $\begin{array}{l}\text { Presentation of trial data: written according to the location of the column; the number of digit } \\
\text { numbers in the column is equalized; the units used are as specified in the table; writing data } \\
\text { according to the rules of important numbers; the data are written following those obtained }\end{array}$ \\
3 & $\begin{array}{l}\text { Write down the data analysis: following experimental data; graph complete with scale; the } \\
\text { writing of the equation is correct; the writing of symbols is correct; data analysis is clear. }\end{array}$ \\
4 & $\begin{array}{l}\text { Summing up the measurement data that has been done: Following the purpose of the } \\
\text { experiment: the existence of explanations whether the appropriate theory or not; use } \\
\text { effective sentences; writing following EYD; the conclusions can be read clearly. }\end{array}$ \\
5 & $\begin{array}{l}\text { Submit a report of measurement results following the time specified } \\
\text { from }\end{array}$
\end{tabular}

Assessment is done with a Likert scale with scale $1-5$, with description value $1=$ If there is one criterion that fulfilled, and so on. While the validation expert uses 12 items are given in Table 3 as follows:

Table 3. Item Validation for Both Verbal And Non-Verbal Instruments

\begin{tabular}{|c|c|}
\hline Num & Rated aspect \\
\hline 1 & $\begin{array}{l}\text { Substance } \\
\text { The rubric structure (objectives, components, values) is structured on the basis of physical } \\
\text { communication skills }\end{array}$ \\
\hline 2 & Conformity of the contents of the rubric with basic competence \\
\hline 3 & The aspect of communication skill set has clear indicators \\
\hline 4 & The aspect of communication skill set has operational indicators \\
\hline 5 & $\begin{array}{l}\text { Construction } \\
\text { The contents of the rubric are arranged systematically from indicators of communication } \\
\text { ability to be observed }\end{array}$ \\
\hline 6 & Rubberries are easy to make judgments \\
\hline 7 & Rubrics are flexible and can be used generally \\
\hline 8 & Shows a proportional score for every aspect of communication skills \\
\hline 9 & A rubric contains clear rubric filling guidelines \\
\hline & Language \\
\hline 10 & Writing the rubric following the rules of the Indonesian language \\
\hline 11 & The language used is organized effectively and communicatively \\
\hline 12 & The language used is easy to understand \\
\hline
\end{tabular}

By criteria: 3.01 to 4.00 : Worth using without revision; 2.01 to 3.00 : Worth using with revision; 1.01 to 2.00: Not worth using.

This study uses a validation process involving 6 validators. The inner validator consists of 3 expert lecturers (physics, education, and evaluation) and 3 high school physics teachers. The validation sheet consists of 3 aspects, namely substance, construction, and language of 12 items. Validation results from the validator then analyzed by using Aiken's V. Item test is valid if the coefficient of validity $\geq 0.78$. The validator assessment results for nontest instruments developed in the validation are described in Table 4.

Non-test instruments are declared valid because all items have a validity coefficient of more than 0.78 . It states that the non-test instrument developed has been compatible with the material, construction, and language aspects. While Genova analysis using EduG produces data as given in Table 5. 
Table 4. Validation Score

\begin{tabular}{|c|c|c|c|c|c|c|c|c|}
\hline \multirow[t]{2}{*}{ Item } & \multicolumn{6}{|c|}{ Validation Score } & \multirow{2}{*}{ CV } & \multirow[t]{2}{*}{ Decision } \\
\hline & \multicolumn{6}{|c|}{ Verbal Aspect } & & \\
\hline 1 & 3 & 3 & 4 & 3 & 4 & 3 & 0.78 & Valid \\
\hline 2 & 4 & 3 & 4 & 3 & 3 & 3 & 0.78 & Valid \\
\hline 3 & 4 & 3 & 4 & 3 & 4 & 3 & 0.83 & Valid \\
\hline 4 & 3 & 3 & 4 & 3 & 4 & 3 & 0.78 & Valid \\
\hline 5 & 4 & 3 & 4 & 3 & 4 & 4 & 0.89 & Valid \\
\hline 6 & 3 & 3 & 4 & 3 & 4 & 3 & 0.78 & Valid \\
\hline 7 & 4 & 3 & 4 & 3 & 4 & 3 & 0.83 & Valid \\
\hline 8 & 4 & 3 & 4 & 3 & 4 & 3 & 0.83 & Valid \\
\hline 9 & 3 & 3 & 4 & 3 & 4 & 3 & 0.78 & Valid \\
\hline 10 & 4 & 3 & 4 & 3 & 4 & 4 & 0.89 & Valid \\
\hline 11 & 4 & 3 & 4 & 3 & 4 & 3 & 0.83 & Valid \\
\hline 12 & 4 & 3 & 4 & 3 & 4 & 3 & 0.83 & Valid \\
\hline \multicolumn{9}{|c|}{ Non Verbal Aspect } \\
\hline 1 & 4 & 3 & 4 & 3 & 4 & 3 & 0.83 & Valid \\
\hline 2 & 4 & 3 & 4 & 4 & 3 & 3 & 0.83 & Valid \\
\hline 3 & 3 & 3 & 4 & 3 & 3 & 4 & 0.78 & Valid \\
\hline 4 & 3 & 3 & 4 & 3 & 3 & 3 & 0.72 & Valid \\
\hline 5 & 3 & 3 & 4 & 3 & 4 & 3 & 0.78 & Valid \\
\hline 6 & 3 & 4 & 4 & 4 & 4 & 4 & 0.94 & Valid \\
\hline 7 & 4 & 3 & 4 & 3 & 4 & 3 & 0.83 & Valid \\
\hline 8 & 4 & 3 & 4 & 4 & 4 & 3 & 0.89 & Valid \\
\hline 9 & 3 & 4 & 4 & 3 & 4 & 3 & 0.83 & Valid \\
\hline 10 & 4 & 3 & 4 & 3 & 4 & 4 & 0.89 & Valid \\
\hline 11 & 4 & 3 & 4 & 4 & 4 & 4 & 0.94 & Valid \\
\hline 12 & 4 & 3 & 4 & 3 & 4 & 4 & 0.89 & Valid \\
\hline
\end{tabular}

Table 5. Reliability of instrument

\begin{tabular}{ccc}
\hline Instrument & Coefficient G Relative & Decision \\
\hline Verbal & 1.00 & Reliable \\
Non-Verbal & 1.00 & Reliable \\
\hline
\end{tabular}

This result directly states that the non-test instrument developed is reliable. This is because the coefficient $\mathrm{G}$ relative has a value greater than 0.7 .

This result corresponding to the aim of the research. This research aims to develop physics communication skill instruments based on local wisdom for Senior High School. Communication skill is divided into two pieces, verbal and nonverbal communication. According to Series (2018), mastery of this skill is essential to improve the quality of learning, especially science learning. From the research, we find the aspect of verbal communication skill, (1) present the presentation in a straight forward manner, (2) master the material presented, (3) able to answer questions, and (4) be open to criticism and suggestion. This way, one of the rated aspects of the ability to present a presentation is delivering physics in a language that is easy to understand. This way is relating to the statement that practicing thinking to communicate something will make students have a better understanding of physics (Lou, Wu, Shih, \& Tseng, 2010).

Students usually take a short conclusion that physics is such a difficult lesson. As stated by Fahmi (2017), lack of student understanding of physics in the classroom make them not confident enough for expressing their opinion. Through the developed assessment, we get a better way to solve it. For active students, it is not a trouble to do presentations, but for the shy one, it is very terrible to express their opinion about physics in front of the class. This developed assessment helps them to do that. They don't have any selection, they must do the assessment, both verbal and nonverbal assessment. The courage to express 
opinions will make their learning result maximal, according to the opinion of Ho (2014). It just showed by the validation score of 12 items presented, the coefficient of validity $\geq 0.78$. that means all items are valid.

The rated aspect of verbal and nonverbal instruments is divided into three parts, (1) substance, (2) construction, and (3) language. Every single rated aspect consists of 3-6 points. According to Koh \& Finkelstein (2005), one of the lack of the cause of student's ability to understanding physics is foreign terms. Of course, it is not a big problem when they apply nonverbal assessments. This assessment forces them well to write the right expression for the term, such us complete the report component, present the trial data, write down the data analysis, summing up the measurement data that has been done, and submit the report of measurement result following the time specified. Based on the research, non-test instruments are declared valid because all items all have a validity coefficient of more than 0.78 .

Appropriate assessment of the model will help the students to maximize their achievement (Yusuf, 2015). Both verbal and nonverbal assessments are helping the teachers to give a standard evaluation for students. A result given by Genova analysis using EduG produces data that both the instruments are reliable with the coefficient $G$ relative 1.00. Correspond to the local wisdom, the instruments will encourage the students to know their culture closer. Learning physics adapted from local wisdom will certainly be a unique moment for students, and the teacher does not need to worry about the assessment after that learning. The development of physics communication skill instruments based on local wisdom will help both students and teachers to maximize their roles to produce the best learning.

\section{Conclusion}

This research developed a physics communication skill instruments based on local wisdom for senior high students, especially grade XI. Based on the result of research and discussion, it can be concluded that all non-test items are valid and reliable. Nontest instruments have represented indicators of physics communication ability to be measured. Physics teachers can apply the instruments in class for assessing student's progress. Meanwhile, they also make the students closer to the nearest local wisdom in their school location. Both teacher and students will maximize their roles to produce the best learning using the instruments.

\section{Acknowledgement}

This article may be written because of the facilities provided by the Graduate Library, Yogyakarta State University, in the process of seeking references. Yogyakarta State University has provided material support in the research and publication of this article. We are always grateful for the help given by the staff of Yogyakarta State University. We would like to extend our deepest acknowledgement to all members of SMA IT Ihsanul Fikri Mungkid Magelang for the support and facilities during the study.

\section{References}

Aiken, L. R. (1985). Three Coefficients for Analyzing the Reliability and Validity of Ratings. Educational and Psychological Measurement, 45(1), 131-142

Adilah, G., \& Saputra, S. (2013). Enhancing Local Wisdom Through Local Content of Elementary School In Java, Indonesia," 11-12

Aydo, B., \& Kartal, S. (2013). The effect of open-ended science experiments based on scenarios on the science process skills of the pre-service teachers, 93, 1162-1168. https://doi.org/10.1016/j.sbspro.2013.10.008

Azwar, Saifuddin. (2014). Reliabilitas dan Validitas. Yogyakarta: Pustaka Pelajar.

Bakhtiar, A. M., Nugroho, A. S., Gresik, U. M., \& Agung, R. (2016). Curriculum Development of Environmental Education Based on Local Wisdom at Elementary, 15(3), 20-28.

Curwood, J. S., Tomitsch, M., Thomson, K., \& Hendry, G. D. (2015). Professional learning in higher education: Understanding how academics interpret student feedback and 
access resources to improve their teaching, 31(5), 556-571.

Dass, R. (2014). Literature and the 21st century learner. Procedia - Social and Behavioral Sciences, 123, 289-298

Demir, S. (2014). Assessment of prospective science teachers ' metacognition and creativity perceptions and scientific toys in terms of scientific creativity, 152, 686-691. https://doi.org/10.1016/j.sbspro.2014.09.263

Dewi, I. N., Poedjiastoeti, S., \& Prahani, B. K. (2017). Elsii learning model based local wisdom to improve students' problem solving skills and scientific communication, 5(1), 107-118.

Fahmi, Rahayu. (2017) . Pengembangan Model Outdoor Learning Melalui Game Berbasis Local Wisdom Berbasis Local Wisdom untuk Meningkatkan Kemampuan Komunikasi dan Hasil Belajar Kognitif Peserta Didik pada Materi Keseimbangan Benda Tegar,",M.Pd. thesis, Deppartmen of Physics, Postgraduate of Yogyakarta State University.

Gök, T., \& Sýlay, I. (2010). The Effects of Problem Solving Strategies on Students' Achievement, Attitude and Motivation. Latin-American Journal of Physics Education, 4, 7-21. Retrieved from http://dialnet.unirioja.es/servlet/articulo?codigo=3694877

Ho, Š. (2014). The Effect of Language Preparation on Communication Skills and Growth of Students self-Confidence, 114, 644-648. https://doi.org/10.1016/j.sbspro.2013.12.761

Hodosyová, M., Útla, J., Vnuková, P., \& Lapitková, V. (2015). The Development of Science Process Skills in Physics Education. Procedia - Social and Behavioral Sciences, 186, 982-989. https://doi.org/10.1016/j.sbspro.2015.04.184

Klisc, C., McGill, T., \& Hobbs, V. (2009). The effect of assessment on the outcomes of asynchronous online discussion as perceived by instructors. Australasian Journal of Educational Technology, 25(5), 666-682.

Kohl, P. B., \& Finkelstein, N. D. (2005). Student representational competence and selfassessment when solving physics problems, (May), 1-11. https://doi.org/10.1103/PhysRevSTPER.1.010104

Lou, S. J., Wu, S. C., Shih, R. C., \& Tseng, K. H. (2010). Adoption of blogging by a Chinese language composition class in a vocational high school in Taiwan. Australasian Journal of Educational Technology, 26(6), 898-916

Mardapi, D. 2012. Pengukuran Penilaian dan Evaluasi Pendidikan. Yogyakarta: Parama Publishing.

Mastura, T., Soh, T., Mohamad, N., \& Osman, K. (2010). The Relationship of 21 st Century Skills on Students' A ttitude and Perception towards Physics, 7(2), 546-554. https://doi.org/10.1016/j.sbspro.2010.10.073

Mungmachon, R. (2002). Knowledge and Local Wisdom: Community Treasure. Miss Roikhwanphut Mungmachon PhD Candidate in Integral Development Studies, 2(13), 174-181.

Musa, F., Mufti, N., Latiff, R. A., \& Amin, M. M. (2012). Project-based learning (PjBL): inculcating soft skills in 21 century workplaces. 59, 565-573

Mustea, A., Mure, M., \& Herman, C. (2014). Integrating E-learning into the transdisciplinary methodology as a solution to the challenges of 21 st century society, 128, 366-372

Ongardwanich, N., Kanjanawasee, S., \& Tuipae, C. (2015). Development of 21 st Century Skill Scales as Perceived by Students. Procedia - Social and Behavioral Sciences, 191, 737-741

Pornpimon, C., Wallapha, A., \& Prayuth, C. (2014). Strategy Challenges the Local Wisdom Applications Sustainability in Schools. Procedia - Social and Behavioral Sciences, 112(Iceepsy 2013), 626-634. https://doi.org/10.1016/j.sbspro.2014.01.1210

Sahin, M. C. (2009). Instructional design principles for 21 st century learning skills, 1(1), $1464-1468$

Series, C. (2018). Enhancing Communication Skills of Pre-service Physics Teacher through HOT Lab Related to Electric Circuit Enhancing Communication Skills of Pre-service Physics Teacher through HOT Lab Related to Electric Circuit. 
Setiawan, B., Innatesari, D. K., \& Sabtiawan, W. B. (2017). Jurnal Pendidikan IPA Indonesia The Development Of Local Wisdom-Based Natural Science Module To Improve Science Literation Of Students, 6(1), 49-54. https://doi.org/10.15294/jpii.v6i1.9595

Stiller, K. D., Freitag, A., Zinnbauer, P., \& Freitag, C. (2009). How pacing of multimedia instructions can influence modality effects: A case of superiority of visual texts. Australasian Journal of Educational Technology, 25(2), 184-203.

Trifu, S., Trifu, A., \& Trifu, I. (2016). Psychic functions and processes with princeps role in learning, 217, 421-429. https://doi.org/10.1016/j.sbspro.2016.02.003

Weeden P.,Winter J., \& Broadfoot, P. 2002. Assesment, What's in it For Schools?. New York: Taylor \& Francis Group.

Young, D dan Freedman, Roger A. 2001. Fisika Universitas. Jakarta: PT. Gelora Aksara Pratama.

Yusuf, A.M. 2015. Asesmen dan Evaluasi Pendidikan. Jakarta: Prenamedia Group. 